\title{
Stemming the gender gap in STEM entrepreneurship - insights into women's entrepreneurship in science, technology, engineering and mathematics
}

\author{
Katherina Kuschel ${ }^{1}$ (D) Kerstin Ettl ${ }^{2}$ (D) Cristina Díaz-García $^{3}$ (D) \\ Gry Agnete Alsos ${ }^{4}$ (D)
}

Published online: 5 March 2020

(C) The Author(s) 2020

\begin{abstract}
Science, technology, engineering, and mathematics (STEM) fields are notably important for innovation and technological development, which in turn are seen as drivers of social and economic growth. Hence, researchers and policy-makers have paid substantial attention to analyzing and promoting high-growth ventures in STEM fields. However, STEM fields are highly gender-skewed, regardless of whether the population considered is students, faculty members, graduates, top managers, or entrepreneurs. This is noticeable in the small number of women entrepreneurs with STEM backgrounds. This underrepresentation of women in innovation-driven business startups highlights existing gender biases and systemic disadvantages in social structures, making visible the double masculinity that exists at the intersection of STEM and entrepreneurship. This article addresses this issue by combining insights from research about women's entrepreneurship and research about the gender aspects of STEM fields. We emphasize institutional, organizational, and individual factors influencing women's entrepreneurship in STEM fields, laying the foundation for the articles included in this special issue. Finally, we discuss the way forward for research on the gender aspects of STEM entrepreneurship to help us create the knowledge needed to close this gender gap.
\end{abstract}

Keywords Women's entrepreneurship · Gender · STEM · Innovation · Technology · Highgrowth ventures

\section{Introduction}

Innovative entrepreneurship contributes to the wealth of nations and their economic dynamism (Decker et al. 2014) through, for instance, job creation (Kuschel et al. 2018).

Gry Agnete Alsos

gry.a.alsos@nord.no

Katherina Kuschel

kkuschel@pucp.edu.pe

Extended author information available on the last page of the article 
Many of those innovative entrepreneurs and their businesses relate to the fields of science, technology, engineering, and mathematics (STEM fields). These STEM fields face a consistent gender gap, and this gender imbalance has a negative effect on productivity, economics and wellbeing (Díaz-García et al. 2013; Settles et al. 2006). The systemic disadvantages that lead to this gender gap in career and occupational choices have been extensively discussed in the literature. There is consensus that the biological argument for cognitive sex-based differences in math and science has lost its plausibility in the modern world (Hyde 2005; Spelke 2005). Instead, research suggests that perceived or actual differences in cognitive performance between males and females are most likely the result of social and cultural factors (Hyde and Mertz 2009), such as experience, educational policies and cultures of gender equality. At the same time, an increasing number of jobs that once required human effort, physical strength and resistance are being replaced with technology, rigid work structures are being dissolved through virtual communication technologies and women are increasingly empowered and educated, so logically we could expect a reduction of gender disparities in the labor market and STEM fields. Nevertheless, socially constructed gender differences and consequential gender inequalities persist, leading to the gender gap in STEM fields (Wang and Degol 2017), the gender gap in entrepreneurship (Kelley et al. 2017) and obstacles to women's entrepreneurship in STEM in particular.

Like gender inequality in any field, gender inequality in STEM has its roots in a complex set of issues. Investigating the roots of women's underrepresentation in STEM is a story of stereotypes, a gender-socialized belief system, and a lack of role models. In the United States, for instance, girls and boys have similar science achievements, yet fewer girls than boys aspire to science careers (Fouad et al. 2010). This paradox emerges in middle school, when peers begin to play a stronger role in shaping adolescent identities. Girls' interest in STEM wanes in middle school, and their selfperceptions of their mathematical abilities relative to boys also plummets at this time (Fouad et al. 2010). The magnitude of these differences may vary according to the high school context, school curriculum, and extracurricular activities (Legewie and DiPrete 2014). Nevertheless, sensitizing girls to STEM as well as to entrepreneurship is a political issue (European Commission/EACEA/Eurydice 2016; National Science and Technology Council 2018). Recent studies show that within higher education, there are no visible gender differences in students' persistence in STEM studies (e.g., Marra et al. 2012; Heilbronner 2013; King 2016), but there are significant gender differences in self-confidence (Eris et al. 2010; Heilbronner 2013).

Traditionally, women have been underrepresented in STEM educational programs as well as in STEM employment and leadership positions (Mavriplis et al. 2010). This may be one reason why few women entrepreneurs are - so far - present in STEM industries (Coleman and Robb 2016). In addition to the low levels of women earning STEM degrees, it seems that women are either opting out or pushed out in various stages of their career development. This is illustrated with the metaphor of the 'leaky pipeline', pointing to the fact that the number of women decreases as career levels advance (Blickenstaff 2005), both in education and in the labor market. According to Fouad et al. (2012), once they graduate from their engineering studies, many women never pursue engineering as a career $(10 \%)$, others leave $(31 \%)$ for reasons such as dissatisfaction with the workplace climate $(21 \%)$ or to spend more time with their family (10\%). This is in line with the results of Hewlett et al. (2008), who found that 
$52 \%$ of women in STEM quit their jobs in their mid- or late thirties. For those who leave, e.g., trained women scientists with breaks in their careers, it is difficult to return to work because they do not fit appropriately into the eligibility conditions of organizations (Ball 2015). However, according to the same study by Fouad et al. (2012), the majority of women (59\%) remained in engineering, and many experienced supportive work environments, including support from their supervisors and coworkers, as well as opportunities for training and development (although only $25 \%$ have access to a mentor). Those women who felt self-confident in navigating their organization's 'political landscape' reported that they have career satisfaction.

The discussion of underrepresentation is similar to that of STEM entrepreneurship. The Global Entrepreneurship Monitor 2018/2019 shows that of the 49 economies included in the survey, only six countries show equal engagement in early-stage entrepreneurial activities (TEA) between men and women (Bosma and Kelley 2018). In particular, Europe and North America have many economies with a lack of gender equality in TEA. When economic development in countries increases, the number of established business activities among women declines, and the gender gap increases (Kelley et al. 2017). With regard to gender differences in entrepreneurship and innovation, the GEM Women's Entrepreneurship Report shows that a country's innovation level increases with its economic development, and "innovation is the indicator with the greatest female-to-male gender ratio; across all 74 economies, women entrepreneurs have a 5\% greater likelihood of innovativeness than men" (Kelley et al. 2017: 9). Therefore, if women do not lack innovativeness, there might be structural barriers that hinder the equal engagement of women in entrepreneurship.

Against this backdrop, we initiated this special issue to encourage research-based knowledge about the gender gap in STEM entrepreneurship. We sought to bring together research from varying perspectives, with multiple methods and theoretical perspectives, thereby seeking insights into the complexity of this topic. In writing this introductory article, we are pleased to see that we succeeded in this aim. The five articles that, after a thorough review and revision process, are included in this issue indeed represent a broad take on this issue; they include important insights for the scholarly community as well as practical discussion of the gender bias of entrepreneurship in STEM fields. In this introductory article, we will further elaborate on the knowledge foundation of this special issue. We combine insight from the literature on women's entrepreneurship and gender in entrepreneurship with insights from the scholarly debate about gender aspects of STEM fields. We propose a three-fold perspective addressing institutional, organizational, and individual factors influencing women's entrepreneurship in STEM. Furthermore, we briefly present the individual articles in this special issue and how they contribute to the ongoing conversation. Finally, considering the current knowledge base and the contributions from the included articles, we discuss implications and highlight areas for future research needed to help us close the gender gap in STEM fields.

\section{Factors driving and hindering women's entrepreneurship in STEM}

As stated previously, very few women pursue entrepreneurship within STEM fields (Coleman and Robb 2016). One subgroup of women who might be in a good position to pursue entrepreneurship are academic women. For example, Rodríguez-Gulías et al. 
(2018) find that since university spin-off organizations (USOs) emerge in a university context that gives female- and male-owned USOs a similar resource endowment and access to similar industries, males and females show comparable growth. However, the majority of the literature supports that women face more difficulties even in an academic context, and only a few women academics create spin-offs (Rosa and Dawson 2006). In comparison to their male counterparts, the number of women in senior academic positions in many scientific disciplines is disproportionately low (Gewin 2011; Sheltzer and Smith 2014), and their numbers are fewer not only in patent licensing but also in consultancy services (Abreu and Grinevich 2017).

As reasons for these differences, researchers have pointed to women academics' family obligations (Busolt and Kugele 2009), gender biases within universities' entrepreneurial ecosystems (Giuri et al. 2018), entrepreneurial financing (Alsos and Ljunggren 2017; Gicheva and Link 2013), entrepreneurship and innovation policy (Ahl and Nelson 2015; Pettersson 2007), academic background (Woolley 2019), and supporting infrastructure such as technology incubators (Marlow and McAdam 2012). Consistent with these studies, Karataş-Özkan and Chell (2015) point to gender inequalities at all levels: at the microlevel (when a scientist achieves an established position, for males, this is the first step in a ladder of career progression; whereas for females, it raises questions about lifestyle choices); at the meso level (some gendered practices have significant bearings on academic career development: high demands for flexibility, mobility and long work hours; and inadequate or missing role models (Kuschel et al. 2017; Byrne et al. 2019), mentoring schemes and incentive mechanisms); and at the macro level (when considering the interrelations between the field of STEM and the external commercial world of technology transfer, women confront gendered language and attitudes towards financial transactions, making and breaking deals, and pushing the growth and development of an idea to its ultimate conclusion; they also need to develop networks of support within a largely male-dominated commercial environment). The literature supports that subjective experiences might differ by gender and lead to women experiencing gender inequalities (Karataş-Özkan and Chell 2015), since it might still be that "the processes, structures and discourses of academic entrepreneurship are constructed and gendered" (Fältholm et al. 2010: 60).

Explanations of women's underrepresentation in male-dominated fields, such as STEM and entrepreneurship, have been subject to debate for decades, and these explanations can be divided into two major categories: characteristics of the individual and characteristics of the environment, both of which, for instance, affect women's academic and career choices, decisions to become entrepreneurs or their likelihood of succeeding. Following Brush et al. (2018), we consider the inextricable influence of different levels in explaining the impact of gender on a phenomenon, in this case, the gender gap of women in STEM entrepreneurship. In the following paragraphs, we highlight selected aspects of the institutional, organizational and individual levels.

\section{Institutional level}

Building upon institutional theory (Scott 2008), Brush et al. (2018) remind us that regulatory, normative, and cognitive institutions can all be of gendered nature, since they might represent 'hidden' aspects, or informal practices, rules, and norms that have a gender dimension. Regulatory institutions are those rules that directly influence the 
costs of starting-conducting-closing a business and any policies that affect the desirability and feasibility of entrepreneurship. Normative institutions influence the desirability of entrepreneurship, determining acceptable roles for individuals within a society and typical role behavior.

Normative institutions are related, for example, to the socialized gender roles that are embedded in occupational values. Accordingly, previous research has documented that persons who especially value occupations that provide opportunities to help others are disproportionately uninterested in STEM careers (Diekman et al. 2011), and this explanation is offered as an account of why females do not pursue STEM careers more often (Su et al. 2009). However, Simon et al. (2017) found that this explanation is more useful for explaining why males do not have even greater overrepresentation in STEM careers, since males with especially altruistic or communitarian occupational values were less likely to major in a STEM field.

Entrepreneurship in STEM areas requires high amounts of investment, and male entrepreneurs are known to raise higher levels of funding than their female counterparts (e.g., Alsos et al. 2006). Cultural-cognitive institutions (such as suppliers, buyers, regulatory agencies, resource providers, or the media) shape the cognitive legitimacy of entrepreneurial new ventures; if accepted, they will have a higher probability of success. However, if - when pitching their ideas to potential customers and investors women fail to successfully convey the value of their product, the new venture's viability and survival chances will be seriously jeopardized, as investors are reluctant to accept women's legitimacy (Balachandra et al. 2019). Additionally, a recent study by Kanze et al. (2018) documents that investors ask promotion-focused questions to male entrepreneurs and prevention-focused questions to female entrepreneurs and, in this way, they induce corresponding responses and perpetuate disparities in funding outcomes (those asked promotion-focused questions raise significantly higher amounts of funding). The authors experimentally prove that entrepreneurs can significantly increase funding for their startups if they respond to prevention-focused questions with promotion-focused answers. Kuschel and Lepeley (2016) argue that some investors (e.g., public funds, business angels, venture capitalists) might not fund women-led startups because of the potential for the leader to become pregnant and make the startup a lower priority, at least temporarily. However, recent studies conducted after the global financial crisis show that women may be less risky loan payers and therefore safer bets for financial institutions (Cowling et al. 2019). Women are found to be more successful at raising money in crowdfunding platforms, as they seem to be better communicators (Gorbatai and Nelson 2015). Such gendered institutions may play out not only at the societal level but also at the organizational and individual levels.

\section{Organizational level}

Following Acker (1990), we note three areas where organizations may be gendered, explaining the gender gap in STEM entrepreneurship. At first, there is the construction of divisions along lines of gender (i.e., division of labor-for example, the horizontal or vertical segregation of work roles and opportunities for women). Second, the construction of symbols and images expresses and reinforces gender divisions-language, ideology, and cultural aspects (i.e., narratives and stories about successful entrepreneurs who act as role models, advertisements for events and competitions that display 
entrepreneurs). Third, there are gendered social structures, including workplace interactions (i.e., gendered norms for behaviors and interactions).

With regard to the first area, gendered division of labor, for example, O'Connor et al. (2006), found that within ICT copreneurial teams, husbands are frequently recognized as the lead founders and tend to work in sales or product development, while wives tend to handle more 'women's work' such as administrative tasks.

Furthermore, there seems to be a gendered construction of the STEM environment. Ulvenblad et al. (2011) assert the existence of gender construction and segregation patterns within Swedish entrepreneurial/innovative learning environments. The authors facilitated focus groups with female participants and found that entrepreneurship education programs were male dominated in terms of the numerical representation of faculty members, students, and guest lecturers and examples of success stories used during classes. Female role models may play a huge role in reducing the gender gap in preference, intention, and ultimately participation and success. However, a randomized experiment in French higher education suggests that role models also increase students' awareness of female underrepresentation in science and reinforce the belief that women are discriminated against STEM careers, which could explain the limited effects of female role models among low-achieving girls (Breda et al. 2018).

Focusing on the interactions at the university level, Simon et al. (2017) confirm that masculinity and femininity are orthogonal personality dimensions and not opposite poles on a single gendered personality continuum. After accounting for occupational values, they found little support for the hypothesis that masculine personality characteristics are especially helpful in STEM majors. However, men who had more abundant feminine personality traits were actually more likely to major in a STEM field (having more positive perceptions of the academic climate, they were less frequently treated unfairly by professors, received more attention in class, and had a greater number of friends in their major). In contrast, they found that women somehow pay a femininity penalty in STEM majors (having significantly fewer friends in the major). Focusing on interactions in their firms or industries, Ezzedeen and Zikic (2012) identify the legitimacy obstacle that women entrepreneurs must face (male investors or customers) and in particular of male subordinates who might oppose them and sabotage their initiatives (a phenomenon known as the "thorny floors").

\section{Individual level}

Individual characteristics such as a person's sense of self-efficacy and agency certainly contribute to one's interest and capability for success in a field. In addition, understanding individual perceptions of gender identity and gender roles and how these perceptions influence career choice are essential to addressing the gender gap in STEM careers. Frome et al. (2006) found that $82 \%$ of women with male-dominated career aspirations in their senior year of high school chose to change their career aspirations by age 25 to either a gender-neutral or female-dominated career. A strong and significant reason for changing career aspirations was a desire for job flexibility, which would allow them to raise a family.

Two barriers also commonly studied for women entrepreneurs in other fields are networks and funding. With regard to networks, it seems that lower numbers of women in a field lead the women members of that field to develop mixed gender networks 
(Hampton et al. 2009) and to use ICTs to engage in networking (Martin and Wright 2005). Additionally, gender bias in incubators (Marlow and McAdam 2012), technology transfer offices (Giuri et al. 2018), and venture capital and entrepreneurial financing (Brush et al. 2018; Alsos and Ljunggren 2017) may make it harder for female entrepreneurs to develop and utilize network contacts.

A study conducted in nanotechnology startups in the U.S. explores the gender, education, and occupational backgrounds of founders, finding the variety of career paths that lead to women starting technology firms (Woolley 2019). The study shows that female and male founders have very similar education and occupational backgrounds. However, women are less likely to have academic backgrounds, and this plays a significant role in the likelihood that their firms suffer a negative closure, are acquired, or obtain venture capital, but in different ways depending on gender.

Women still attribute a high proportion of encountered challenges (at the personal, firm, and industry levels) to their gender, and they are accustomed to resolving challenges through personal solutions: becoming an "honorary man" (Martin et al. 2015: 175), acting like the boys 'to fit in' (Marlow and McAdam 2012), and being ready to engage in 'game playing' (Marlow and McAdam 2015). This process of assimilation might be common in male-dominated fields such as STEM. However, industry-related support structures, especially a women's mentoring program, would be welcome (Orser et al. 2012).

\section{Selected articles on women's entrepreneurship in STEM}

This special issue includes five articles. One article is a systematic literature review related to women's entrepreneurship in STEM; two articles focus on drivers of women's entrepreneurial intentions in technological fields (competences, co-learning); and two other articles focus on issues women have to deal with when working within STEM fields (team compositions that improve performance, and the ways in which women negotiate and define their technological entrepreneurial identity). Table 1 provides a brief overview of the individual contributions.

The first paper, by Sara Poggesi, Michela Mari, Luisa De Vita, and Lene Foss (in this issue), explores the published management research on women entrepreneurs' STEM fields and offers a first, comprehensive state-of-the-art assessment of this emerging research area. The article presents the results from a systematic literature review (SLR) of 32 articles, which have been categorized according to the career paths of the sample: academic women entrepreneurs and non-academic women entrepreneurs. The articles in these two clusters are systematically analyzed along three dimensions: the gender issue, the main topic investigated by the authors and the suggested implications, both for research and practice. Their results reinforce Jennings and Brush's (2013) point that there exists scant knowledge of women engaged in academic entrepreneurship and technology transfer.

In paper 2, Catherine Mavriplis, Catherine Elliott, and Hanan Anis (in this issue) analyze the results of a peer mentoring program for women engineering and computer science students in Canada, which was developed to provide training and support to a small group of entrepreneurs. This paper reports the experiences of peer mentors in the program, observing an increase in both entrepreneurial self-efficacy (ESE) and 
Table 1 Overview of contributions in this special issue

\begin{tabular}{|c|c|c|c|}
\hline Authors & Research question(s) & Research design & Main findings \\
\hline $\begin{array}{c}\text { Poggesi } \\
\text { et al. }\end{array}$ & $\begin{array}{l}\text { What is the state-of-the-art of } \\
\text { women entrepreneurs in } \\
\text { STEM fields? }\end{array}$ & $\begin{array}{l}\text { - Systematic literature review } \\
\text { - Sample: } 32 \text { scientific articles } \\
\text { from Scopus, WoS, and } \\
\text { EBSCO databases }\end{array}$ & $\begin{array}{l}\text { Lack of studies on women } \\
\text { engaged in academic } \\
\text { entrepreneurship and } \\
\text { technology transfer. }\end{array}$ \\
\hline $\begin{array}{l}\text { Mavriplis } \\
\text { et al. }\end{array}$ & $\begin{array}{l}\text { What are the experiences of } \\
\text { mentors in a peer mentoring } \\
\text { program, in terms of } \\
\text { entrepreneurial self-efficacy } \\
\text { (ESE) and entrepreneurial } \\
\text { intentions (EI)? }\end{array}$ & $\begin{array}{l}\text { - Empirical paper } \\
\text { - Mixed methods approach } \\
\text { - Sample: female engineering } \\
\text { and computer science } \\
\text { students in Canada }\end{array}$ & $\begin{array}{l}\text { Mentorship boosts } \\
\text { self-confidence, awareness } \\
\text { of diversity and gender } \\
\text { issues, and a changed } \\
\text { perspective on technical } \\
\text { problem-solving and life in } \\
\text { general. }\end{array}$ \\
\hline $\begin{array}{c}\text { Armuña } \\
\text { et al. }\end{array}$ & $\begin{array}{l}\text { How do entrepreneurship } \\
\text { competences affect STEM } \\
\text { women's intention to start } \\
\text { up a business in a university } \\
\text { setting? }\end{array}$ & $\begin{array}{l}\text { - Empirical paper } \\
\text { - Quantitative } \\
\text { - Sample: Male and female } \\
\text { participants in the } \\
\text { ActuaUPM } 2017 \\
\text { STEM-related program of a } \\
\text { university in Spain }\end{array}$ & $\begin{array}{l}\text { Gender does not have an } \\
\text { impact on technological } \\
\text { entrepreneurship intention. }\end{array}$ \\
\hline $\begin{array}{l}\text { Neumeyer } \\
\quad \& \\
\text { Santos }\end{array}$ & $\begin{array}{l}\text { What is the effect of gender } \\
\text { (individual differences and } \\
\text { team composition) on the } \\
\text { performance of } \\
\text { technology-based entrepre- } \\
\text { neurial teams? }\end{array}$ & $\begin{array}{l}\text { - Empirical paper } \\
\text { - Sample: Survey of } 30 \text { teams } \\
\text { enrolled in a team-based } \\
\text { entrepreneurship university } \\
\text { program and judge's eval- } \\
\text { uations (academic years } \\
\text { 2012-2014) in the U.S. }\end{array}$ & $\begin{array}{l}\text { The proportion of women and } \\
\text { the existence of multiplex } \\
\text { ties among team members } \\
\text { have a positive influence on } \\
\text { team performance, while } \\
\text { number of team factions is } \\
\text { negatively related to team } \\
\text { performance. }\end{array}$ \\
\hline Birkner & $\begin{array}{l}\text { Does the genderedness of } \\
\text { entrepreneurial normative } \\
\text { frames serve as a chance or } \\
\text { challenge for women } \\
\text { STEMpreneurs in the } \\
\text { context of accomplishing } \\
\text { entrepreneurial belonging? }\end{array}$ & $\begin{array}{l}\text { - Empirical paper } \\
\text { - Qualitative approach } \\
\text { - Sample: } 30 \text { interviews with } \\
\text { women entrepreneurs in } \\
\text { German-speaking countries }\end{array}$ & $\begin{array}{l}\text { Women in STEM can } \\
\text { strategically choose to } \\
\text { "belong or not" to the given } \\
\text { masculine normative frame. }\end{array}$ \\
\hline
\end{tabular}

entrepreneurial intent (EI), although perhaps not immediately after graduation, since this program might have made the participants aware of what resources and capabilities they need to gain to start a venture with higher chances of success. That is, for women, experiences of colearning can be important in developing entrepreneurial self-efficacy and intention.

In paper 3, Cristina Armuña, Sergio Ramos, Jesús Juan Ruiz, Claudio Feijoo, and Alberto Arenal (in this issue) find that gender does not have an impact on technological entrepreneurship intention and that entrepreneurship education models have to focus on the development of soft skills (identification of opportunities, commitment,

decision-making and organization) since they play a greater role in influencing entrepreneurial intention than do specific knowledge on economics or finance. The ability to identify and value potential opportunities results in the most influential competence with regard to entrepreneurship intention, followed by perceptions of abilities related to commitment, decision-making, and teams' organization. 
In paper 4, Xaver Neumeyer and Susana Santos (in this issue) explore the impact of gender composition ratios (proportion of women in teams) and aspects of team dynamics such as communication frequency, multiplexity and the formation of subgroups on the performance of technology-based entrepreneurial teams. This article uses data collected in three time periods from 30 teams enrolled in a university program in the United States. The authors find that the proportion of women and the existence of multiplex ties among team members (both professional and friendship relationships) have a positive influence on team performance, while the number of team factions (subgroups and their communication frequency) is negatively related to team performance. Implications for team-based entrepreneurship programs and women are presented.

In paper 5, Stephanie Birkner (in this issue) contributes to the current discussion on how women entrepreneurs are affected by the challenges of defining and negotiating their entrepreneurial identity. By applying the theoretical perspective of liminality, she sheds light on how women can strategically adapt their actions and choose whether they enact some identity characteristics or not. This article has implications for how we understand the challenges women with STEM backgrounds face when entering entrepreneurship and seeking to develop their entrepreneurial identity.

\section{Discussion and calls for future research}

Women are consistently underrepresented within STEM fields, in education, in science, in employment, and in management positions (Beede et al. 2011; Legewie and DiPrete 2014). Although women's engagement in entrepreneurial activity has increased over the years, there are still significantly more men than women entrepreneurs in most countries around the world (Kelley et al. 2015). Hence, it is not surprising that there is also a gender gap in STEM-related entrepreneurship. This gap is problematic for several reasons. On the one hand, the failure to recruit more women to STEM-based entrepreneurship restricts the supply of human capital into this important area and hampers innovation. On the other hand, this skewness limits opportunities for women as entrepreneurs within fields where earnings are higher, startups have higher growth expectations, and both public support systems and private venture capital tend to focus. The reasons for the gender gap in STEM entrepreneurship are many and complex. The articles in this special issue have pointed to several different aspects of this complex topic.

First, the articles offer insights related to women already in STEM and their decisions to become entrepreneurs. Armuña et al. (2020) disconfirm the commonly held wisdom that fewer women than men in STEM have entrepreneurial intentions but support the idea that increasing entrepreneurial competences - specifically in opportunity identification and evaluation - contributes positively to the development of entrepreneurial intentions in potential STEM entrepreneurs. Hence, while we should not focus on whether women are different from men per se, there might be reason to look into how entrepreneurial competences are developed, in which arenas, and who is included. Mavriplis et al. (2020) point to gender-sensitive entrepreneurship education as a way to develop such competences. Importantly, they also emphasize the role of identity for development of entrepreneurial intentions and show that entrepreneurship 
education combined with mentoring can support identity formation. Another implication that can be drawn from Armuña et al.'s and Mavriplis et al.'s findings is that we need to focus beyond entrepreneurial intentions to understand the gender gap in STEM entrepreneurship.

Second, the articles provide insights into the gendered process of becoming an entrepreneur in the STEM fields. Birkner (2020) discusses how women STEM entrepreneurs work to obtain 'entrepreneurial belonging' in this very masculine area. She finds that the process of accomplishing entrepreneurial belonging implies dealing with the perceived opposition between 'being a woman' and 'being an entrepreneur' within the STEM fields; women are also affected by a lack of harmony between these two identities, which requires a dynamic and adaptable approach to doing and undoing gender. Hence, she points to the process of developing one's identity as an entrepreneur as an interactive process between the woman and her environments, a process in which 'doing gender' (West and Zimmerman 1987) is an important part. In this process, women entrepreneurs need to navigate the expectations from actors in their environment as well as their own expectations about what it means to be an entrepreneur in this area (Hytti et al. 2017). Poggesi et al. (2020) argue that women STEM entrepreneurs face a context that is double masculinized, both by the masculinization of the STEM fields and by the masculinization of entrepreneurship. In this context, their strategies often involve 'leaning in' (Sandberg 2013), i.e., adopting behaviors similar to the men in the field and seeking to 'fit in' (see also Marlow and McAdam 2015).

Third, the articles in this issue provide some insights into the outcomes of women's entrepreneurship in the STEM field. Importantly, acknowledging that STEM entrepreneurship is predominantly team-based, Neumeyer and Santos (2020) investigate the impact of the gender composition of such teams. They find that more gender-balanced teams have better team dynamics and, consequently, better team performance. This finding resonates with the current literature on gender diversity in management teams more generally (e.g., Hoogendoorn et al. 2013), management teams in STEM fields (Ruiz-Jiménez et al. 2016), and innovation teams (Díaz-García et al. 2013; Kuschel et al. 2018; Woolley 2019).

The contributions from the included articles provide important insights to help clarify the gender aspects of STEM entrepreneurship. However, they also document the crucial limitations imposed by the lack of research in this area. While research on women's entrepreneurship has bloomed over the last decades (Jennings and Brush 2013), covering a wide range of areas, the academic literature discussing women entrepreneurs in the STEM fields in particular is still scarce. Furthermore, the literature on women in STEM fields only very seldom focuses on entrepreneurship as a potential career. Moreover, although the discussion of the gendered nature of entrepreneurship, entrepreneurship policy and entrepreneurship practice has recently been advanced through strong feminist contributions (Ahl and Nelson 2015; Calás et al. 2009; Marlow and Martinez Dy 2018; Mirchandani 1999), the number of studies approaching STEM entrepreneurship with a feminist analysis is very limited.

Hence, we echo Poggesi et al. (2020) on the need for enhancing research on women's STEM entrepreneurship as well as gendered analyses of STEM 
entrepreneurship; together, we call for more research, broader theoretical perspectives, and investigation of a wider range of relevant topics. Given the scarcity, research is needed in many areas. We particularly point to the following directions for future research:

First, there is a need to define and explore the characteristics of women's entrepreneurship within the STEM fields. We lack an overview of the magnitude of the phenomenon and how it has developed, as well as how the gender gap in STEM entrepreneurship relates to women's underrepresentation in the types of positions from which scientists typically launch new ventures (Stephan and El-Ganainy 2007). Descriptive analyses of differences between different STEM fields, the role of teams in women's STEM entrepreneurship, and on the links between STEM education, STEM research and STEM entrepreneurship would be helpful in better understanding this area. For this purpose, clearer definitions of STEM, STEM entrepreneurship and women's STEM entrepreneurship (e.g., related to team positions and ownership) are needed.

Second, we would like to see research on women in STEM more often explore entrepreneurship as an option for STEM graduates. How does entrepreneurship relate to the problem with the 'leaky pipeline' (Blickenstaff 2005; Cannady et al. 2014) or the 'vanish box' (Etzkowitz and Ranga 2011). What are the gendered processes of 'opting out' of STEM jobs and into STEM entrepreneurship and to what extent is entrepreneurship applauded or discouraged?

Third, we call for research that goes beyond the early recruitment of women to STEM entrepreneurship and beyond analyzing how the characteristics of the women correlate with the (lack of) involvement in STEM entrepreneurship. We would like to see studies focusing on the process of becoming STEM entrepreneurs, the gendered nature of the STEM context (see, e.g., Marlow and McAdam 2012, 2015), as well as how this leads to different outcomes of entrepreneurial processes within the STEM areas. How do women STEM entrepreneurs navigate their 'otherness' in such a strongly masculinized context? Are there alternative strategies to 'leaning in' when creating their identity and behaviors? How and why do women enter STEM entrepreneurship, and how and why do they exit?

Fourth, we see a need for more research on the gendered nature of entrepreneurial ecosystems (Brush et al. 2019), with a particular focus on technology entrepreneurial ecosystems. There is evidence of the gendered construction of entrepreneurship policy (e.g., Ahl and Nelson 2015), entrepreneurship support systems (Marlow and McAdam 2012), and entrepreneurial finance (Brush et al. 2018; Malmström et al. 2017). However, we lack analyses focused on STEM fields in particular, an area where ecosystems and supporting actors are particularly important for successful engagement in entrepreneurship.

Finally, there is a need for more advanced feminist analyses in the area of STEM entrepreneurship. We need to better understand how gender is constructed and 'done' in this specific context, how the context itself is gendered, and how this identity construction influences the entrepreneurship efforts of women, men, and multigendered teams. Hence, we agree with Poggesi et al. (2020) that "future research should improve the analysis of the interactions among entrepreneurship, masculinity, femininity, and technology further, by not only investigating women entrepreneurs in STEM, but also men". In fact, we suggest that masculinity theory and research can advance insights into STEM entrepreneurship processes and help us understand how gender plays a role in this context. 
Acknowledgments We thank Salvador Roig for his editorial advice throughout the publication process of this special issue. We are deeply grateful for the time and constructive advice of our reviewers, without whom we could not have produced this special issue.

Funding Information Open Access funding provided by Nord University.

Open Access This article is licensed under a Creative Commons Attribution 4.0 International License, which permits use, sharing, adaptation, distribution and reproduction in any medium or format, as long as you give appropriate credit to the original author(s) and the source, provide a link to the Creative Commons licence, and indicate if changes were made. The images or other third party material in this article are included in the article's Creative Commons licence, unless indicated otherwise in a credit line to the material. If material is not included in the article's Creative Commons licence and your intended use is not permitted by statutory regulation or exceeds the permitted use, you will need to obtain permission directly from the copyright holder. To view a copy of this licence, visit http://creativecommons.org/licenses/by/4.0/.

\section{References}

Abreu, M., \& Grinevich, V. (2017). Gender patterns in academic entrepreneurship. The Journal of Technology Transfer, 42(4), 763-794.

Acker, J. (1990). Hierarchies, jobs, bodies: a theory of gendered organizations. Gender \& Society, 4(2), 139158.

Ahl, H., \& Nelson, T. (2015). How policy positions women entrepreneurs: a comparative analysis of state discourse in Sweden and the United States. Journal of Business Venturing, 30(2), 273-291.

Alsos, G. A., \& Ljunggren, E. (2017). The role of gender in entrepreneur-investor relationships: a signaling theory approach. Entrepreneurship: Theory \& Practice, 41(4), 567-590.

Alsos, G. A., Isaksen, E. J., \& Ljunggren, E. (2006). New venture financing and subsequent business growth in men- and women-led businesses. Entrepreneurship Theory and Practice, 30(5), 667-686.

Armuña, C., Ramos, S., Ruiz, J. J., Feijoo, C., \& Arenal, A. (2020). From stand-up to start-up: exploring entrepreneurship competences and STEM women's intention. International Entrepreneurship and Management Journal (this issue).

Balachandra, L., Briggs, T., Eddleston, K., \& Brush, C. (2019). Don't pitch like a girl!: how gender stereotypes influence investor decisions. Entrepreneurship Theory and Practice, 43(1), 116-137.

Ball, C. (2015). Returning to a career in the biosciences after an extended break. Biochemical Society. April 2015, 49-50. http://www.biochemist.org/bio/03702/0049/037020049.pdf. Accessed 3 May 2019.

Beede, D. N., Julian, T. A., Langdon, D., McKittrick, G., Khan, B., \& Doms, M. E. (2011). Women in STEM: a gender gap to innovation. Economics and Statistics Administration Issue Brief, 04-11.

Birkner, S. (2020). To belong or not to belong, that is the question?! Explorative insights on liminal gender states within women's STEMpreneurship. International Entrepreneurship and Management Journal (this issue).

Blickenstaff, J. C. (2005). Women and science careers: Leaky pipeline or gender filter? Gender and Education, 17(4), 369386.

Bosma, N., \& Kelley, N. (2018). Global Entrepreneurship Monitor. 2018/2019 Global Report. https://www. gemconsortium.org/report. Accessed 31 May 2019.

Breda, T., Grenet, J., Monnet, M., \& Van Effenterre, C. (2018). Can female role models reduce the gender gap in science? Evidence from classroom interventions in French high schools. 2018. Ffhalshs-01713068. https://hals-hs.archives-ouvertes.fr/halshs-01713068/document. Accessed 31 May 2019.

Brush, C., Greene, P., Balachandra, L., \& Davis, A. (2018). The gender gap in venture capital-progress, problems, and perspectives. Venture Capital, 20(2), 115-136.

Brush, C., Edelman, L. F., Manolova, T., \& Welter, F. (2019). A gendered look at entrepreneurship ecosystems. Small Business Economics, 53(2), 393-408. https://doi.org/10.1007/s11187-018-9992-9.

Busolt, U., \& Kugele, K. (2009). The gender innovation and research productivity gap in Europe. International Journal of Innovation and Sustainable Development, 4(2-3), 109-122.

Byrne, J., Fattoum, S., \& Díaz-García, M. C. (2019). Role models and women entrepreneurs: entrepreneurial superwoman has her say. Journal of Small Business Management, 57(1), 154-184. 
Calás, M. B., Smircich, L., \& Bourne, K. A. (2009). Extending the boundaries: reframing "entrepreneurship as social change" through feminist perspectives. Academy of Management Review, 34(3), 552-569.

Cannady, M. A., Greenwald, E., \& Harris, K. N. (2014). Problematizing the STEM pipeline metaphor: is the STEM pipeline metaphor serving our students and the STEM workforce? Science Education, 98(3), 443460.

Coleman, S., \& Robb, A. (2016). The next wave: Financing women's growth oriented firms. Palo Alto: Stanford University Press.

Cowling, M., Marlow, S., \& Liu, W. (2019). Gender and bank lending after the global financial crisis: are women entrepreneurs safer bets? Small Business Economics, 1-28. https://doi.org/10.1007/s11187-01900168-3.

Decker, R., Haltiwanger, J., Jarmin, R., \& Miranda, J. (2014). The role of entrepreneurship in US job creation and economic dynamism. The Journal of Economic Perspectives, 28(3), 3-24.

Díaz-García, C., González-Moreno, A., \& Sáez-Martínez, F. (2013). Gender diversity within R\&D teams: its impact on radicalness of innovation. Innovation, 15(2), 149-160.

Diekman, A. B., Clark, E. K., Johnston, A. M., Brown, E. R., \& Steinberg, M. (2011). Malleability in communal goals and beliefs influences attraction to STEM careers: evidence for a goal congruity perspective. Journal of Personality and Social Psychology, 101(5), 902-918.

Eris, O., Chachra, D., Chen, H. L., Sheppard, S., Ludlow, L., Rosca, C., Bailey, T., \& Toye, G. (2010). Outcomes of a longitudinal administration of the persistence in engineering survey. Journal of Engineering Education, 99(4), 371-395.

Etzkowitz, H., \& Ranga, M. (2011). Gender dynamics in science and technology: from the "leaky pipeline" to the "vanish box". Brussels Economic Review, 54(2/3), 131-147.

European Commission/EACEA/Eurydice (2016). Entrepreneurship education at School in Europe. Eurydice report. Luxembourg: Publications Office of the European Union. https://publications.europa. eu/en/publication-detail/-/publication/74a7d356-dc53-11e5-8fea-01aa75ed71a1/language-en. Accessed 31 May 2019.

Ezzedeen, S. R., \& Zikic, J. (2012). Entrepreneurial experiences of women in Canadian high technology. International Journal of Gender and Entrepreneurship, 4(1), 44-64.

Fältholm, Y., Abrahamsson, L., \& Källhammer, E. (2010). Academic entrepreneurship: gendered discourses and ghettos. Journal of Technology Management \& Innovation, 5(1), 51-63.

Fouad, N. A., Hackett, G., Smith, P. L., Kantamneni, N., Fitzpatrick, M., Haag, S., \& Spencer, D. (2010). Barriers and supports for continuing in mathematics and science: gender and educational level differences. Journal of Vocational Behavior, 77(3), 361-373.

Fouad N. A., Singh R., Fitzpatrick M. E., \& Liu J. P. (2012). STEMing the tide: Why women leave engineering. https:/ucd-advance.ucdavis.edu/post/steming-tide-why-women-leave-engineering. Accessed 25 Aug 2017.

Frome, P. M., Alfeld, C. J., Eccles, J. S., \& Barber, B. L. (2006). Why don't they want a male-dominated job? An investigation of young women who changed their occupational aspirations. Educational Research and Evaluation, 12(4), 359-372.

Gewin, V. (2011). Gender divide in physics spans globe. Nature, 473, 547. https://doi.org/10.1038/nj7348-547 a.

Gicheva, D., \& Link, A. (2013). Leveraging entrepreneurship through private investments: does gender matter? Small Business Economics, 40(2), 199-210.

Giuri, P., Grimaldi, R., Kochenkova, A., Munari, F., \& Toschi, L. (2018). The effects of university-level policies on women's participation in academic patenting in Italy. The Journal of Technology Transfer, 129.

Gorbatai, A. D., \& Nelson, L. (2015). Gender and the language of Crowdfunding. Academy of Management Proceedings, 2015(1), 15785.

Hampton, A., Cooper, S., \& McGowan, P. (2009). Female entrepreneurial networks and networking activity in technology-based ventures: an exploratory study. International Small Business Journal, 27(2), 193-214.

Heilbronner, N. N. (2013). The STEM pathway for women - what has changed? Gifted Child Quarterly, 57(1), 39-55.

Hewlett, S. A., Luce, C. B., \& Servon, L. J. (2008). Stopping the exodus of women in science. Harvard Business Review, June 2008. https://hbr.org/2008/06/stopping-the-exodus-of-women-in-science. Accessed 31 May 2019.

Hoogendoorn, S., Oosterbeek, H., \& Van Praag, M. (2013). The impact of gender diversity on the performance of business teams: evidence from a field experiment. Management Science, 59(7), 1514-1528.

Hyde, J. S. (2005). The gender similarities hypothesis. American Psychologist, 60(6), 581-592. 
Hyde, J. S., \& Mertz, J. E. (2009). Gender, culture and mathematics performance. Proceedings of the National Academy of Sciences, 106(22), 8801-8807.

Hytti, U., Alsos, G. A., Heinonen, J., \& Ljunggren, E. (2017). Navigating the family business: a gendered analysis of identity construction of daughters. International Small Business Journal, 35(6), 665-686.

Jennings, J. E., \& Brush, C. G. (2013). Research on women entrepreneurs: challenges to (and from) the broader entrepreneurship literature? Academy of Management Annals, 7(1), 663-715.

Kanze, D., Huang, L., Conley, M. A., \& Higgins, E. T. (2018). We ask men to win \& women not to lose: closing the gender gap in startup funding. Academy of Management Journal, 61(2), 586-614.

Karataş-Özkan, M., \& Chell, E. (2015). Gender inequalities in academic innovation and enterprise: a Bourdieuian analysis. British Journal of Management, 26(1), 109-125.

Kelley, D., Brush, C., Greene, P., Herrington, M., Ali, A., \& Kew, P. (2015). The global entrepreneurship monitor Women's report. Wellesley, MA.

Kelley, D. J., Baumer, B. S., Brush, C., Greene, P. G., Mahdavi, M., Majbouri, M., Cole, M., Dean, M., \& Heavlow, R. (2017). Global Entrepreneurship Monitor. Women's Entrepreneurship 2016/2017 Report. Wellesley, MA.

King, B. (2016). Does postsecondary persistence in STEM vary by gender? AERA Open, 2(4), 1-10.

Kuschel, K., \& Lepeley, M. T. (2016). Copreneurial women in start-ups: growth-oriented or lifestyle? An aid for technology industry investors. Academia Revista Latinoamericana de Administración, 29(2), 181197.

Kuschel, K., Lepeley, M. T., Espinosa, F., \& Gutiérrez, S. (2017). Funding challenges of Latin American women start-up founders in the technology industry. Cross Cultural \& Strategic Management, 24(2), 310331.

Kuschel, K., Labra, J. P., \& Diaz, G. (2018). Women-led startups and their contribution to job creation. In O. Terzidis \& A. Presse (Eds.), Technology entrepreneurship - Insights in new technology-based firms, research spin-offs and corporate environments (pp. 139-156). Cham: Springer.

Legewie, J., \& DiPrete, T. A. (2014). The high school environment and the gender gap in science and engineering. Sociology of Education, 87(4), 259-280.

Malmström, M., Johansson, J., \& Wincent, J. (2017). Gender stereotypes and venture support decisions: how governmental venture capitalists socially construct entrepreneurs' potential. Entrepreneurship Theory and Practice, 41(5), 833-860.

Marlow, S., \& Martinez Dy, A. (2018). Annual review article: is it time to rethink the gender agenda in entrepreneurship research? International Small Business Journal, 36(1), 3-22.

Marlow, S., \& McAdam, M. (2012). Analyzing the influence of gender upon high-technology venturing within the context of business incubation. Entrepreneurship Theory and Practice, 36(4), 655-676.

Marlow, S., \& McAdam, M. (2015). Incubation or induction? Gendered identity work in the context of technology business incubation. Entrepreneurship Theory and Practice, 39(4), 791-816.

Marra, R. M., Rodgers, K. A., Shen, D., \& Bogue, B. (2012). Leaving engineering: a multi-year single institution study. Journal of Engineering Education, 101(1), 6-27.

Martin, L. M., \& Wright, L. T. (2005). No gender in cyberspace? Empowering entrepreneurship and innovation in female-run ICT small firms. International Journal of Entrepreneurial Behavior \& Research, 11(2), 162-178.

Martin, L., Wright, L., Beaven, Z., \& Matlay, H. (2015). An unusual job for a woman? Female entrepreneurs in scientific, engineering and technology sectors. International Journal of Entrepreneurial Behavior \& Research, 21(4), 539-556.

Mavriplis, C., Heller, R., Beil, C., Dam, K., Yassinskaya, N., Shaw, M., \& Sorensen, C. (2010). Mind the gap: women in STEM career breaks. Journal of Technology Management \& Innovation, 5(1), 140-151.

Mavriplis, C., Elliot, C., \& Anis, H. (2020). An entrepreneurship education and peer mentoring program for women in STEM: mentors' experiences and perceptions of entrepreneurial self-efficacy and intent. International Entrepreneurship and Management Journal (this issue).

Mirchandani, K. (1999). Feminist insight on gendered work: new directions in research on women and entrepreneurship. Gender, Work and Organization, 6(4), 224-235.

National Science \& Technology Council (2018). Chartering a course for success: America's strategy for STEM Education. December 2018. https://www.whitehouse.gov/wp-content/uploads/2018/12/STEMEducation-Strategic-Plan-2018.pdf. Accessed 31 May 2019.

Neumeyer, X., \& Santos, S. C. (2020). A lot of different flowers make a bouquet: the effect of gender composition on technology-based entrepreneurial student teams. International Entrepreneurship and Management Journal (this issue). 
O'Connor, V., Hamouda, A., McKeon, H., Henry, C., \& Johnston, K. (2006). Co-entrepreneurial ventures: a study of mixed gender founders of ICT companies in Ireland. Journal of Small Business and Enterprise Development, 13(4), 600-619.

Orser, B., Riding, A., \& Stanley, J. (2012). Perceived career challenges and response strategies of women in the advanced technology sector. Entrepreneurship \& Regional Development, 24(1/2), 73-93.

Pettersson, K. (2007). Men and male as the norm? A gender perspective on innovation policies in Denmark, Finland and Sweden. Stockholm: Nordregio.

Poggesi, S., Mari, M., De Vita, L., \& Foss, L. (2020). Women entrepreneurship in STEM fields: Literature review and future research avenues. International Entrepreneurship and Management Journal (this issue).

Rodríguez-Gulías, M. J., Fernández-López, S., \& Rodeiro-Pazos, D. (2018). Gender differences in growth of Spanish university spin-offs. Gender in Management: An International Journal, 33(2), 86-103.

Rosa, P., \& Dawson, A. (2006). Gender and the commercialization of university science: academic founders of spinout companies. Entrepreneurship and Regional Development, 18(4), 341-366.

Ruiz-Jiménez, J. M., del Mar Fuentes-Fuentes, M., \& Ruiz-Arroyo, M. (2016). Knowledge combination capability and innovation: the effects of gender diversity on top management teams in technology-based firms. Journal of Business Ethics, 135(3), 503-515.

Sandberg, S. (2013). Lean in: Women, work and the will to. Lead: Random House.

Scott, W. R. (2008). Institutions and organizations: Ideas and interests. Thousand Oaks: Sage.

Settles, I. H., Cortina, L. M., Malley, J., \& Stewart, A. J. (2006). The climate for women in academic science: the good, the bad, and the changeable. Psychology of Women Quarterly, 30(1), 47-58. https://doi. org/10.1111/j.1471-6402.2006.00261.x.

Sheltzer, J. M., \& Smith, J. C. (2014). Elite male faculty in the life sciences employ fewer women. Proceedings of the National Academy of Sciences of the United States of America, 111(28), 1010710112. https://doi.org/10.1073/pnas.1403334111.

Simon, R. M., Wagner, A., \& Killion, B. (2017). Gender and choosing a STEM major in college: femininity, masculinity, chilly climate, and occupational values. Journal of Research in Science Teaching, 54(3), 299-323.

Spelke, E. S. (2005). Sex differences in intrinsic aptitude for mathematics and science?: A critical review. American Psychologist, 60(9), 950-958.

Stephan, P. E., \& El-Ganainy, A. (2007). The entrepreneurial puzzle: explaining the gender gap. The Journal of Technology Transfer, 32(5), 475-487.

Su, R., Rounds, J., \& Armstrong, P. I. (2009). Men and things, women and people: a meta-analysis of sex differences in interests. Psychological Bulletin, 135(6), 859-884.

Ulvenblad, P., Blomkvist, M., \& Hansson, A. (2011). World-class entrepreneurship- and innovation programmes in Sweden - focus on gender perceptions. Washington: International Council for Small Business (ICSB).

Wang, M. T., \& Degol, J. L. (2017). Gender gap in science, technology, engineering, and mathematics (STEM): current knowledge, implications for practice, policy, and future directions. Educational Psychology Review, 29(1), 119-140.

West, C., \& Zimmerman, D. H. (1987). Doing gender. Gender \& Society, 1(2), 125-151.

Woolley, J. L. (2019). Gender, education, and occupation: how founder experiences influence firm outcomes. Academy of Management Discoveries, 5(3), 266-290.

Publisher's note Springer Nature remains neutral with regard to jurisdictional claims in published maps and institutional affiliations.

\section{Affiliations}

\section{Katherina Kuschel ${ }^{1} \cdot$ Kerstin Ettl $^{2} \cdot$ Cristina Díaz-García $^{3} \cdot$ Gry Agnete Alsos $^{4}$}

1 CENTRUM Católica Graduate Business School, Pontificia Universidad Católica del Perú, Calle Alomía Robles 125, Lima, Peru

2 Juniorprofessorship for Entrepreneurial Diversity \& SME Management, Universität Siegen, Kohlbettstr. 15, D-57072 Siegen, Germany

3 Facultad de Ciencias Económicas y Empresariales, Universidad de Castilla La Mancha, Plaza de la Universidad 1, 02071 Albacete, Spain

4 Nord University Business School, P.O. Box 1490, NO8049 Bodø, Norway 